\title{
FACTORS AFFECTING ON THE PERFORMANCE OF MECHANICAL HARVESTING MACHINE FOR PLANTED WHEAT CROP ON RAISED BEDS
}

\author{
Omar, O. A. ${ }^{1}$, A.M. El Shal ${ }^{2}$ and Soha G. Abd El Hamid ${ }^{3}$
}

\begin{abstract}
The aim of this study is using the mechanical harvesting to suit the harvesting of the planted wheat crop on raised beds with respect to harvesting grains losses, cutting height, energy, and cost for exploiting the advantages of the raised beds cultivation. Three different machines were used for harvesting wheat crop planted on raised beds namely: Claas, Yanmar combines as well as the front mounted reciprocating mower which harvested wheat in rows that followed by threshing machine were tested and compared to each other. The practical experiments of this study were carried out to evaluate the performance of the harvesting machines under four forward speeds of 1.2,1.8, 2.5 and $3.7 \mathrm{~km} / \mathrm{h}$, four grain moisture content of 12.5, 15.2, 17.3 and $19.7 \%$ taking into consideration the total grain losses, actual field capacity, consumed energy and criterion cost. This study recommended to use the Claas combine for harvesting the planted wheat crop on raised beds at forward speed of $1.8 \mathrm{~km} / \mathrm{h}$ and grain moisture content of $19.7 \%$ for achieving lowest criterion cost of $374.48 \mathrm{LE} / \mathrm{fed}$ and actual field capacity of 1.18 $\mathrm{fed} / \mathrm{h}$ with $4.05 \%$ of total grain losses, and consumed energy of 31.33 kW.h/fed. The highest criterion cost with Claas, Yanmar combine and front mower were 621.25,739.48 and 959.69 LE/fed at forward speed of $3.7 \mathrm{~km} / \mathrm{h}$ and grain moisture content of $12.5 \%$.
\end{abstract}

Keywords: wheat crop, raised beds, harvesting, combines, mower, threshing

\section{INTRODUCTION}

W heat is one of the most important food staff in consumption where more than 50 percent of energy is provided by eating wheat bread in the developing countries.

\footnotetext{
${ }^{1}$ Senior Researcher, Agric. Eng. Res. Inst.(AEnRI), Dokki, Giza, Egypt

${ }^{2}$ Assistant Prof., Agric. Eng. Dept., Fac. of Agric., Zagazig Univ., Egypt.

${ }^{3}$ Researcher, Agric. Eng. Res. Inst.(AEnRI), Dokki, Giza, Egypt
} 
planted wheat on raised beds decrease the amount of water consumed in irrigation and amount of grains for planting ranging approximately between 25-30\%, Siemens and Hulick (2008) stated that, the selfpropelled combine has quickly become the predominant method for harvesting cereal grains. Over time, the size, power and capacity of these machines have increased concomitantly with farm size. Although the modern combine is a highly productive and efficient machine for harvesting and cleaning grain. Mostofi (2011) investigated the Claas 68s combine has gained the most appropriate response to machine performance in hillside area. It has lower loss rate in lower yield than country mean yield that is because of having small diameter of drum in comparison with tested combines. Combine Claas 68 s with $4.12 \%$ overall loss and 3.69 ton/h combine capacity. Hassen et al. (1994) found that, total grain losses and criterion cost for combine were minimum and performance efficiency was maximum under the following conditions: forward speed of $2.1 \mathrm{~km} / \mathrm{h}$, cylinder speed of $2.5 \mathrm{~m} / \mathrm{s}$, and grain moisture content of $12.5 \%$. Increasing forward speed from 2.1 to $3.9 \mathrm{~km} / \mathrm{h}$ at constant grain moisture content of $19.2 \%$ increased header losses from 0.82 to $1.3 \%$, from 0.72 to $1.09 \%$ and from 0.22 to $0.87 \%$ when using Yanmar, Deutz and Fortschritt combines of wheat crop respectively. Moussa (2008) found that, total grain losses were increased with increasing forward speeds and decreasing moisture contents. The highest total grain losses for combine Claas and mower were $7.19 \%$ and $3.98 \%$ respectively at forward speed of $3.9 \mathrm{~km} / \mathrm{h}$ and grain moisture content of $12.1 \%$, while the lowest total grain losses for combine Claas was $4.2 \%$ at forward speed of $1.9 \mathrm{~km} / \mathrm{h}$ and moisture content of $16.58 \%$. Spokas et al. (2016) found that grain moisture content and conditions of the crop stand have a significant effect on the indicators of the combine harvester when compared with its technological parameters and crop mass flow. Awady et al. (1982) stated that, the criterion cost of comparing different harvesting methods includes operating cost, losses evaluated at the current market price. The minimum criterion cost includes the most economical method. Ismail et al. (2009) indicated that, the harvesting costs up to $35 \%$ of the total machinery costs. This emphasizes the need for developing robust methods for choosing the optimum harvesting 
equipment. So the aim of this study to use the mechanical harvesting such as; combines (Claas and Yanmar) and the reciprocating mower to suit the harvesting of the wheat planted on raised beds with respect to harvesting losses, energy and cost.

\section{MATERIALS AND METHODS}

\section{A- Materials}

The experiments were conducted at Qniat district, Zagazig, Sharkia Governorate during summer season 2014/ 2015 for harvesting wheat crop (variety of Gemiza 9), as shown in Table (1) which has been planted on raised beds. Two combine harvesters (Claas - Yanmar) were tested and compared to another mechanical mounted mower on tractor.

Table (1): Some values of wheat plant (Gemiza 9) which planted on raised beds.

\begin{tabular}{|l|c|}
\hline Plant height, $\mathrm{cm}$ & 93 \\
\hline No. of grains per panicle & 63 \\
\hline No. of panicle $/ \mathrm{m}^{2}$ & 321 \\
\hline Yield, $\mathrm{Mg} / \mathrm{fed}$ & 3 \\
\hline
\end{tabular}

\section{-Tractors types:}

- Kubota tractor 295 LD (used with mounted mower):

Made in: Japan.

Engine power: $29 \mathrm{hp}(21.34 \mathrm{~kW})$.

Engine type: Three cylinders', Four stroke diesel with direct injection.

- Universal 650-M (used with thresher machine):

Made in: Romania.

Engine power: $75 \mathrm{hp}(55.93 \mathrm{~kW})$.

Engine type: Four stroke diesel with direct injection.

\section{- Developed Seed drill:}

Developed seed drill which cultivated wheat plants on raised beds Model tye - with width of $240 \mathrm{~cm}$ and three ridgers with width of $120 \mathrm{~cm}$ 
from bottom to bottom and on upper to upper raised beds $93 \mathrm{~cm}$ for each one as shown in Fig. (1).

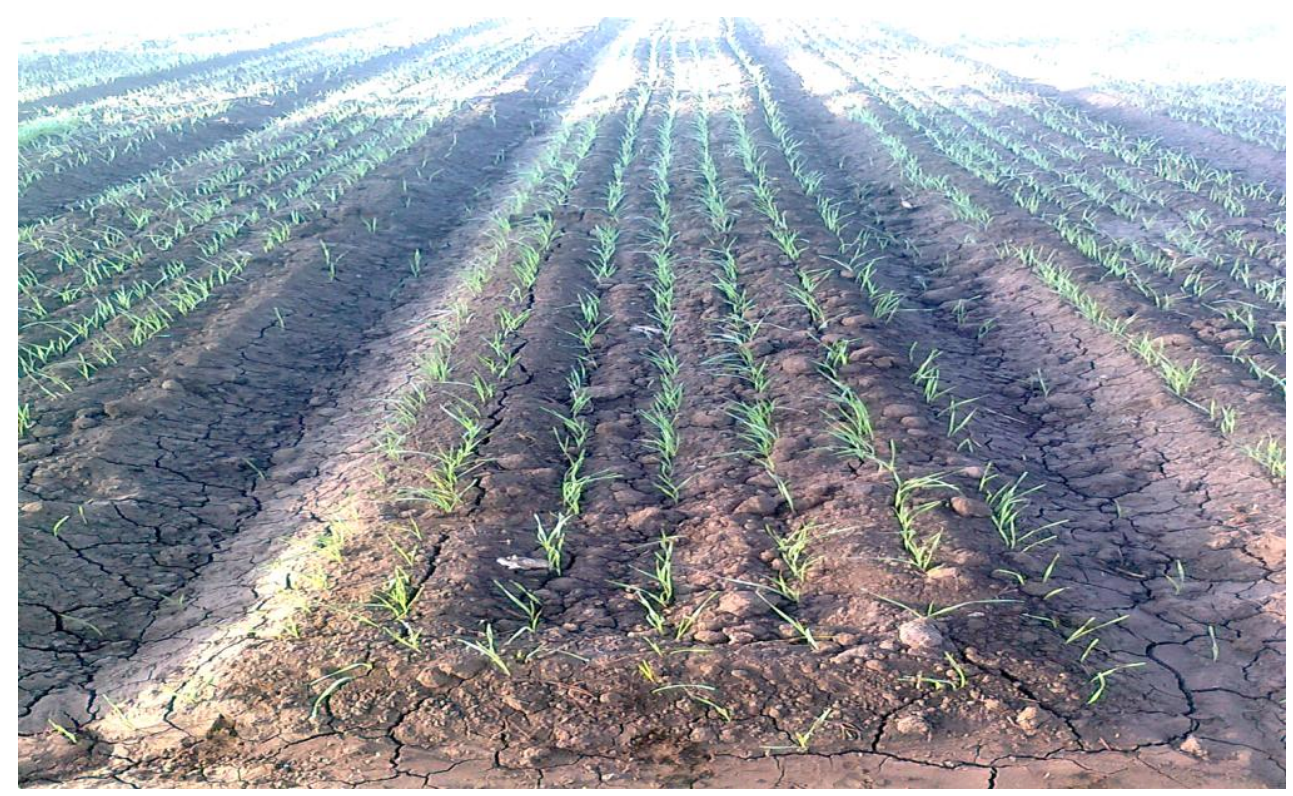

Fig. (1): The cultivated wheat plants on raised beds

\section{Harvesting machines:}

\section{1- Claas medion-310 combine:}

Model AR 120 provided with diesel Engine, threshing drum rotating speed of $2500 \mathrm{rpm}$ and cutting width of $450 \mathrm{~cm}$.

\section{2-The Yanmar combine:}

Model CA 385 EG provided with output engine $(\mathrm{kW} / \mathrm{rpm})$ of $38 / 2800$, threshing drum rotating speed of $520 \mathrm{rpm}$ and cutting width of $140 \mathrm{~cm}$.

\section{3- Front mounted mower:}

It is a hydraulic control double acting mower with cutting width of 150 $\mathrm{cm}$ and mass of $210 \mathrm{~kg}$. The mower was mounted behind the tractor to make balance during harvesting, where the tractor was prepared to suit harvesting with this position to increase the mower efficiency. 

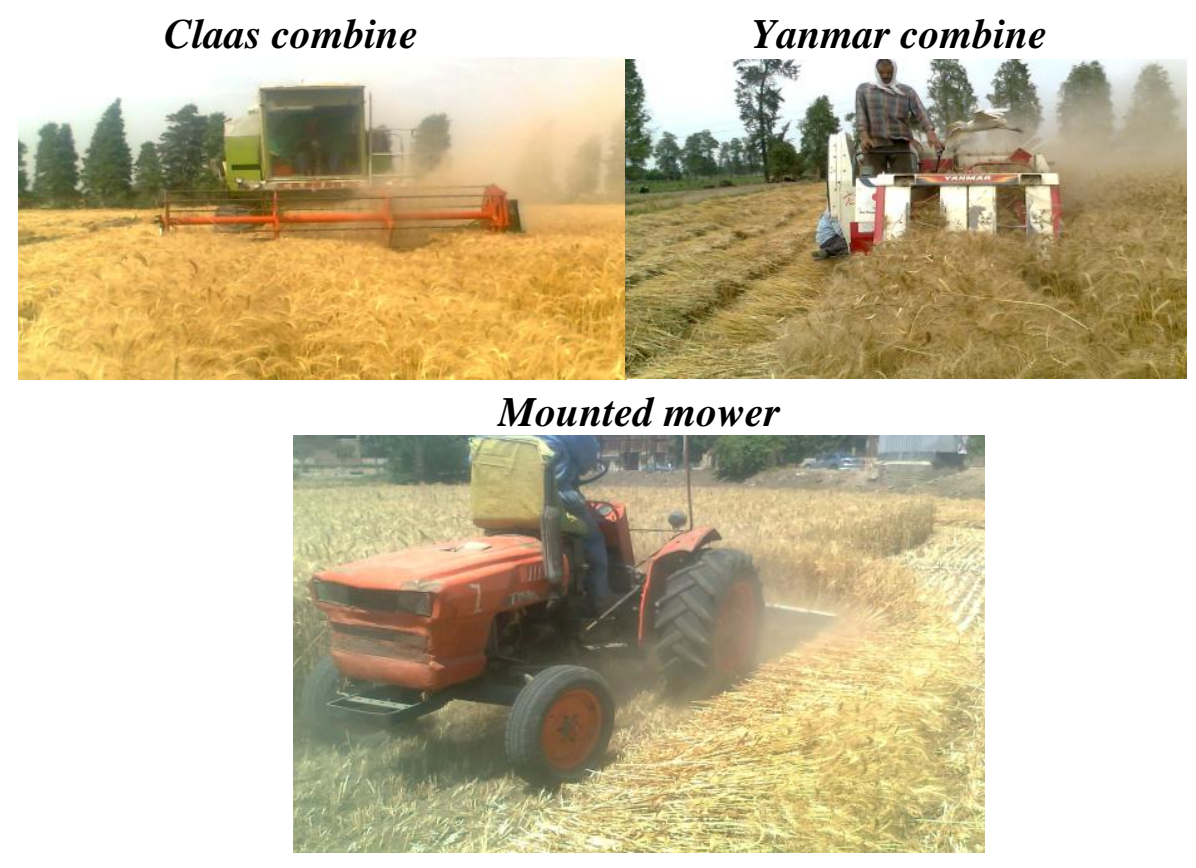

Fig. (2): The harvesting machines.

\section{Thresher machine:}

It is a Turkish threshing machine (spike tooth drum of length $120 \mathrm{~cm}$ ) was used for threshing wheat after harvesting by the front mounted mower.

\section{$\underline{\text { B- Methods }}$}

The evaluation procedures for the harvesting machines during the harvesting process of the planted Wheat on raised beds were carried out using the following variables:

1- Four forward speeds of 1.2, 1.8, 2.5 and $3.7 \mathrm{~km} / \mathrm{h}$.

2-Four moisture contents of 12.5, 15.2, 17.3 and 19.7\% for grains.

3- Three different harvesting systems (Claas combine, Yanmar combine and front mounted mower followed by thresher).

All the practical experiments were conducted under the previous variables and taking into consideration the following indicators: 


\section{1-Harvesting losses:}

\section{Grain losses:}

Grain losses were measured as follows:

\section{Pre-harvesting losses:}

Pre-harvest losses were determined by locating a square meter frame in the un-harvested area and the grain losses in the frame were counted. The percentage of pre-harvested losses was calculated by using the following equation:

$$
\operatorname{Pr} e-\text { harvesting losses }(\%)=\frac{\text { weight of grains on the ground before harvesting /fed }}{\text { Total yield/fed }} \times 100
$$

\section{Mower and combine header losses:}

Mower and combine losses were obtained by locating a frame of square meter on the ground in front of the combine. During the harvesting operation, the combine was stopped at a point where the cutter bar had passed over the frame, but the drive wheels had not. The combine was then backed to access the sample. The grain losses in the frame represent pre-harvest and header losses together. Then for indicating the header losses only, the pre-harvest losses must be subtracted. The percentage of header losses was calculated by using the following equation:

$$
\text { Harvesting losses } \quad(\%)=\frac{H}{T} \times 100
$$

Where:

$\mathrm{H}=$ Mass of grain losses, $\mathrm{kg} / \mathrm{m}^{2}$.

$\mathrm{T}=$ Total grain yield, $\mathrm{kg} / \mathrm{m}^{2}$.

\section{Thresher losses:}

Thresher losses included damaged and un-threshed grains were calculated as follows:

$$
\begin{aligned}
& \text { Grains damage }(\%)=\frac{\text { weight of grains damage }}{\text { Total weight of grains }} \times 100 \\
& \text { Un-threshed grains }(\%)=\frac{\text { weight of unthreshed grains }}{\text { Total weight of grains }} \times 100
\end{aligned}
$$

Total thresher losses $=$ damaged grains + un-threshed grains. 


\section{2- Actual field capacity (A.F.C):}

Field capacity was measured for each case by recording the operating time for combines and mower, ignoring transportation time. Also, feed rate $1.12 \mathrm{Mg} / \mathrm{h}$ has been recorded for thresher as:

$$
\text { Actual field capacity }(\text { fed } / h)=\frac{1}{\text { Total time in hours required per fed }}
$$

\section{3- The power requirement:}

The following formula was used to estimate Power (P), as given by Embaby, (1985):

$\mathrm{P}=(\mathrm{Fc} / 3600) \times \rho_{\mathrm{f}} \times$ L.C.V x $427 \times \eta_{\mathrm{th}} \times \eta_{\mathrm{m}} \times(1 / 75) \times(1 / 1.36), \mathrm{kW}$.

Where:

$\mathrm{Fc}=$ Fuel consumption, $\mathrm{L} / \mathrm{h}$

$\rho_{\mathrm{f}}=$ Density of fuel, $\mathrm{kg} / \mathrm{L}(0.85 \mathrm{~kg} / \mathrm{L}$ for diesel fuel

L.C.V = Lower Calorific Value of fuel, $\mathrm{kcal} / \mathrm{kg}(10000 \mathrm{kcal} / \mathrm{kg}$ for diesel $)$

$427=$ thermo-mechanical equivalent, $\mathrm{kg} \cdot \mathrm{m} / \mathrm{kcal}$

$\eta_{\mathrm{th}}=$ Thermal efficiency of the engine, (40\% for diesel engine)

$\eta_{\mathrm{m}}=$ Mechanical efficiency of the engine, ( $80 \%$ for diesel engine)

\section{4-Energy requirement:}

The following formula was used to calculate the energy requirements for combines and mower:

Energy requirmene $t(k W . h / f e d)=\frac{\text { Power }, k W}{\text { Actual field capacity , fed } . / h}$

The following formula was used to calculate the energy requirements for thresher:

Energy requiremen $t(k W . h / M g)=\frac{\text { Power }, k W}{\text { Feed rate }, M g / h}$ 


\section{5-Yield:}

Yield was recorded as a final target for harvesting operation. Three random samples were taken for each experimental plot. Aluminum square frame $1 \times 1 \mathrm{~m}$ has been made as a sampler to determine yield per Feddan (weight of grains $/ \mathrm{m}^{2}$ ).

\section{6- Cost:}

The cost of different operations was estimated considering the conventional way of estimating both fixed and variable costs: The value of grain losses for wheat has been considered at the different field speeds and grain moisture contents; besides, the operating cost for combines and mower was calculated by the following equations:

$$
\mathrm{C}=\frac{\mathrm{p}}{\mathrm{h}}\left(\frac{1}{\mathrm{a}}+\frac{\mathrm{i}}{2}+\mathrm{t}+\mathrm{r}\right)+(0.9 \text { W.F.S })+\frac{\mathrm{m}}{144},(\text { Awady, 1978) }
$$

Where:

C - Hourly cost; L.E/h

$\mathrm{P}$ - Price of the machine; L.E

$\mathrm{h}$ - Yearly working hours; h/y

a - Life expectancy of the machine; $y$

$\mathrm{i}$ - Interest rate / year; \%

$\mathrm{t}$ - Taxes over heads ratio; \%

$\mathrm{r}$ - Repairs and maintenance ratio; \%

W - Power; hp

$\mathrm{F}$ - Specific fuel consumption; $\mathrm{L} / \mathrm{h}$

$\mathrm{S}-$ Fuel price; L.E

$\mathrm{m}$ - Operator monthly salary; L.E

0.9- Factor a counting for ratio of rated power and lubrications;

144- The monthly average working hours; $h$

Operating $\cos t(L . E / f e d)=\frac{\text { Machine } \cos t, L . E . / h}{\text { Actual field capacity }, \text { fed } . / \mathrm{h}}$

The operating cost for thresher was calculated by the following equation: 
Operating $\cos t($ L.E./Mg $)=\frac{\text { Machine } \cos t, L . E . / h}{\text { Feed rate }, M g / h}$

The criterion cost $=$ Operating cost + Value of grain losses, $\mathrm{L} \cdot \mathrm{E} / \mathrm{Mg}$

\section{RESULTS AND DISCUSSION}

The obtained data will discuss under the following topics:

\section{1- Effect of forward speed on harvesting grain losses under different moisture contents:}

The obtained results indicated that, harvesting grain losses is related to the harvester forward speed. The obtained results showed that, increasing forward speed increased harvesting grain losses, where at increasing forward speed from 1.2 to $3.7 \mathrm{~km} / \mathrm{h}$, harvesting grain losses increased from $1.6 \%$ to $2.52 \%$, from $1.3 \%$ to $2.6 \%$ and $1.0 \%$ to $2.2 \%$ at moisture content of $19.7 \%$ and about $2.8 \%$ to $3.45 \%$, from $2.1 \%$ to $3.8 \%$ and $1.9 \%$ to $3.3 \%$ at moisture content of $12.5 \%$ under Claas, Yanmar combines and front mounted mower respectively. Fig. (3) illustrate that the highest values was $3.45 \%, 3.8 \%$ and $3.3 \%$ it recorded under forward speed of 3.7 $\mathrm{km} / \mathrm{h}$ and at moisture content of $12.5 \%$ for Claas, Yanmar combines and front mounted mower respectively. This can be attributed to the vibration of the header harvesting and the system of gathering, cutting and transporting which is considered more effective for Yanmar combine.

\section{2-Effect of forward speed on threshing losses under Claas and Yanmar combines:}

The obtained data showed that threshing losses is related to forward speed for combines only. The obtained results showed that the threshing grain losses increased with increasing forward speed from 1.2 to $3.7 \mathrm{~km} / \mathrm{h}$, threshing losses increased from $2.3 \%$ to $3.2 \%$, from $3.6 \%$ to $4.6 \%$ at moisture content of $19.7 \%$ and about $3.2 \%$ to $4.1 \%$, from $4.7 \%$ to $5.1 \%$ at moisture content of $12.5 \%$ under Claas and Yanmar combines, respectively. Fig. (4) illustrate that the highest values was $4.1 \%$ and $5.1 \%$ it recorded under forward speed of $3.7 \mathrm{~km} / \mathrm{h}$ at moisture content of 


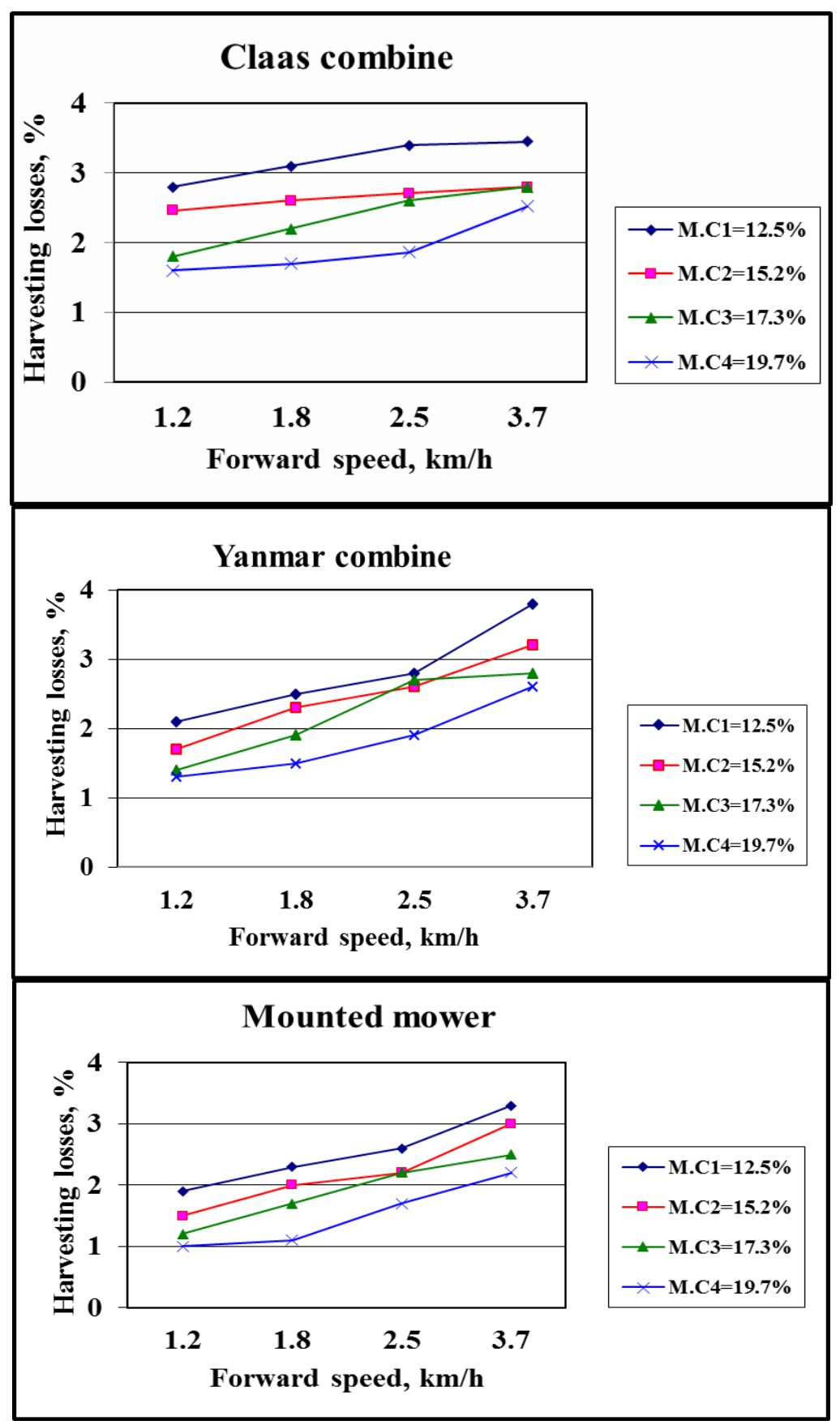

Fig. (3) Effect of forward speed on harvesting losses with using Claas and Yanmar combines and mounted mower under different moisture contents. 


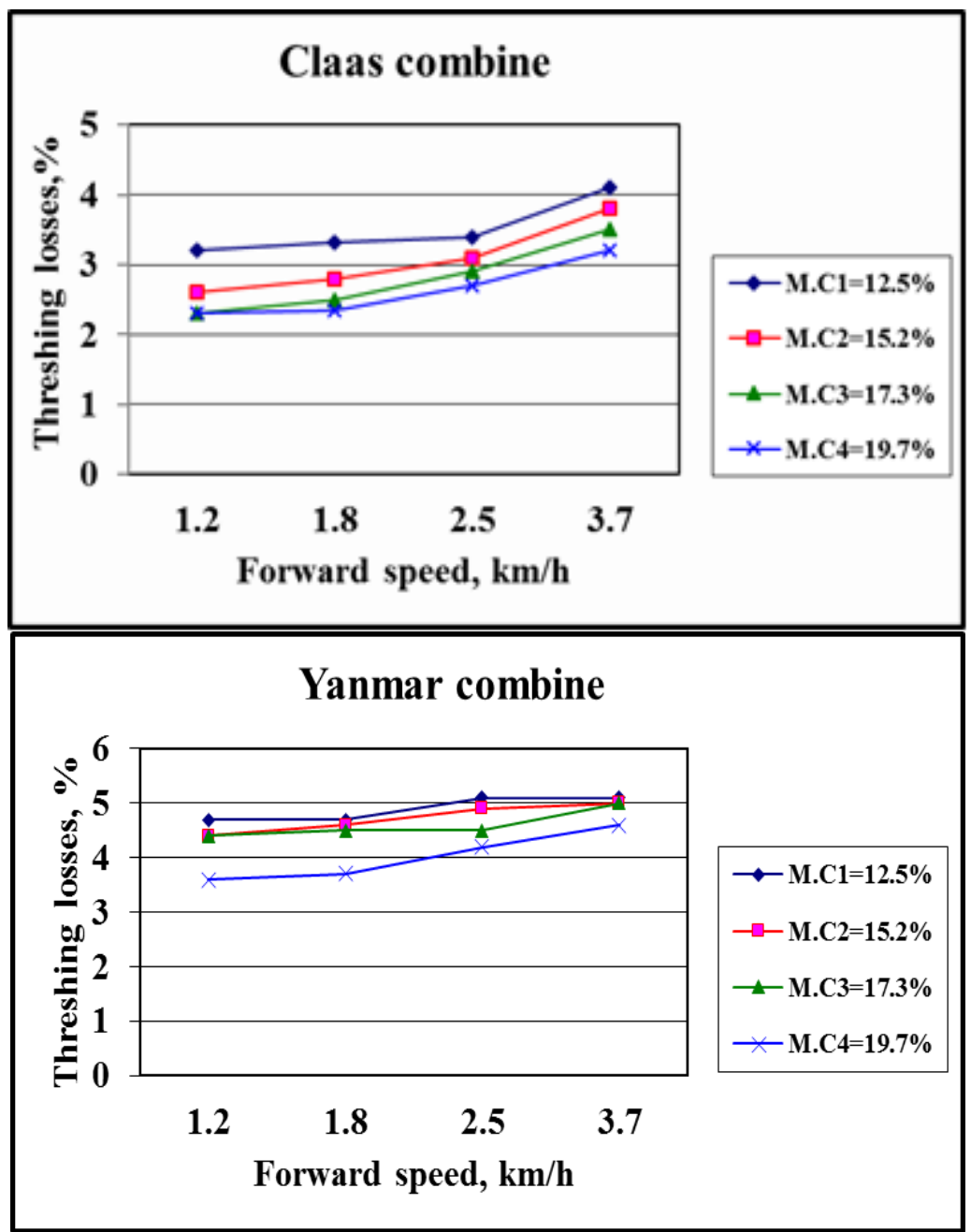

Fig. (4) Effect of forward speed on threshing losses with using Claas and Yanmar combines under different moisture contents.

$12.5 \%$, for Claas and Yanmar combines respectively. This can be due to the increase in the percentage of damaged grains from threshing process and grains separated from threshed straw walker effectiveness, in addition to separated grains from the chaff. Threshing losses (unthreshed and damaged grains) by thresher machine were 3.25, 3.4, 3.5 and 3.62\% under moisture contents of $19.7,17.3,15.2$ and $12.5 \%$ respectively at feed rate $1.12 \mathrm{Mg} / \mathrm{h}$ and drum speed of $600 \mathrm{rpm}$ for thresher machine. 


\section{3- Effect of forward speed on total grain losses under different moisture contents:}

The obtained results showed that, the total grain losses increased with increasing forward speed, where at increasing forward speed from 1.2 to $3.7 \mathrm{~km} / \mathrm{h}$, the total losses increased from $3.9 \%$ to $5.72 \%$, from $4.9 \%$ to $7.2 \%$ at moisture content of $19.7 \%$ and about $6.0 \%$ to $7.55 \%$, from $6.8 \%$ to $8.9 \%$ at moisture content of $12.5 \%$ under Claas and Yanmar combines respectively. Fig. (5) illustrate that the highest total grain losses were $8.9 \%$ using Yanmar combine at forward speed of $3.7 \mathrm{~km} / \mathrm{h}$ and moisture content of $12.5 \%$, this is may be due to increasing the percentage of harvesting and threshing losses, the lowest total grain losses were $3.9 \%$ at forward speed of $1.2 \mathrm{~km} / \mathrm{h}$ and moisture content of $19.7 \%$ using Claas combine, this is may be due to decreasing the percentage of harvesting and threshing losses. The total grain losses at harvesting by front mounted mower then thresher machine increased with increasing moisture content, the minimum value was $4.25 \%$ at moisture content $19.7 \%$, and forward speed of $1.2 \mathrm{~km} / \mathrm{h}$ while the highest value was $6.92 \%$ at moisture content of $12.5 \%$ and forward speed of $3.7 \mathrm{~km} / \mathrm{h}$.

\section{4- Effect of harvesting methods on the cutting height at different forward speeds and moisture contents of plants:}

It is no doubt that the harvester forward speed and moisture content of plant play a vital role in determining the cutting height. As absolute values, the front mower gave the lowest cutting height. It was recorded $2.8 \mathrm{~cm}$ at forward speed of $1.2 \mathrm{~km} / \mathrm{h}$, while the Claas combine gave the highest cutting height $25.1 \mathrm{~cm}$ at moisture content of $19.7 \%$ and forward speed $3.7 \mathrm{~km} / \mathrm{h}$. Fig. (6) The obtained results show that, increasing forward speed from 1.2 to $3.7 \mathrm{~km} / \mathrm{h}$ at grain moisture content of $19.7 \%$ would increase cutting height from $18.6 \mathrm{~cm}$ to $25.1 \mathrm{~cm}$, from $14.0 \mathrm{~cm}$ to $18.3 \mathrm{~cm}$ and $3.7 \mathrm{~cm}$ to $6.1 \mathrm{~cm}$ under Claas, Yanmar and front mounted mower respectively. With decreasing moisture content to $12.5 \%$ the cutting height decreasing to $17.1 \mathrm{~cm}, 13.4 \mathrm{~cm}$ and $2.8 \mathrm{~cm}$ at forward speed of $1.2 \mathrm{~km} / \mathrm{h}$ under Claas, Yanmar and front mounted mower respectively. 


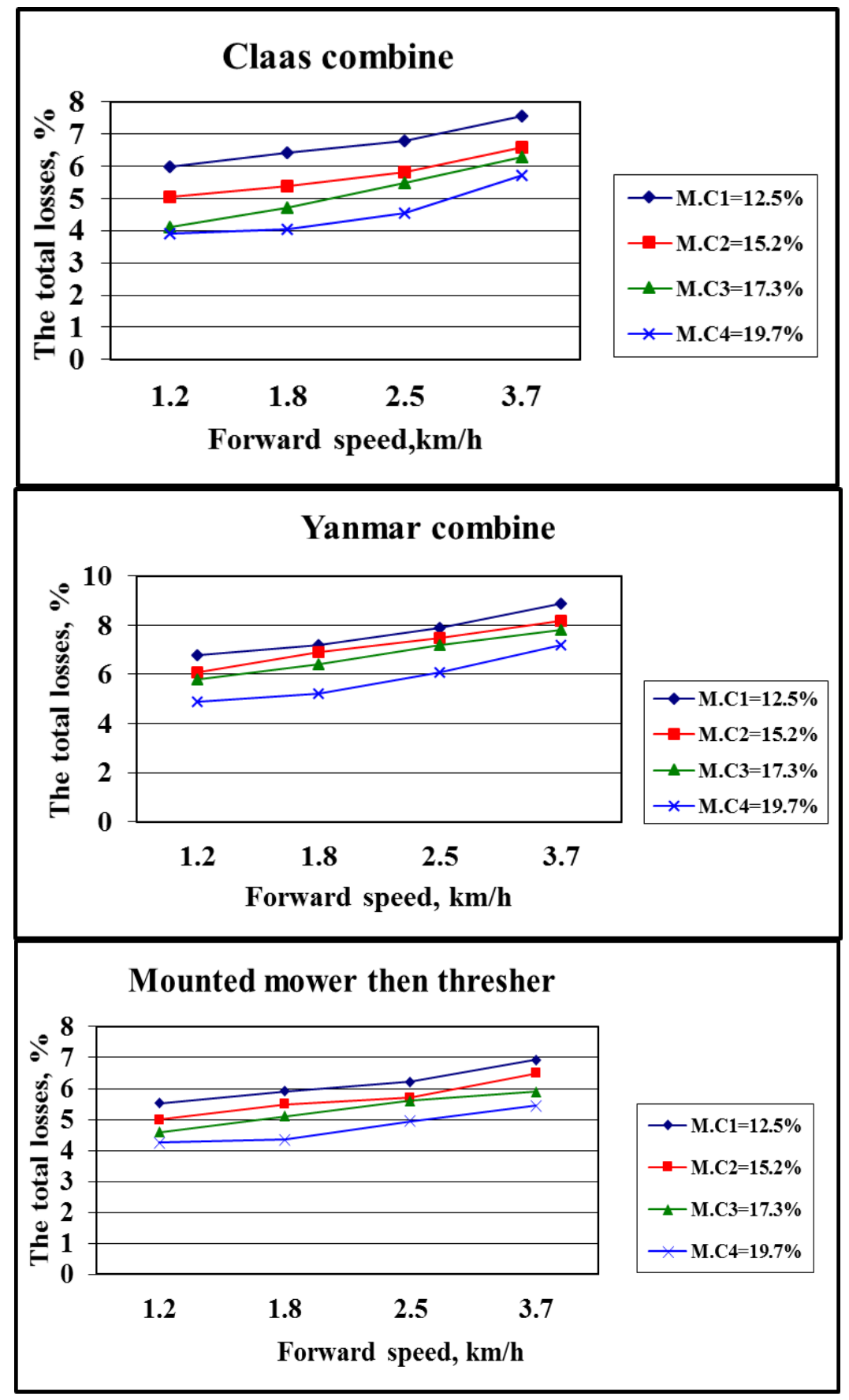

Fig. (5) Effect of forward speed on the total losses with using Claas, Yanmar combines and mounted mower under different moisture contents. 


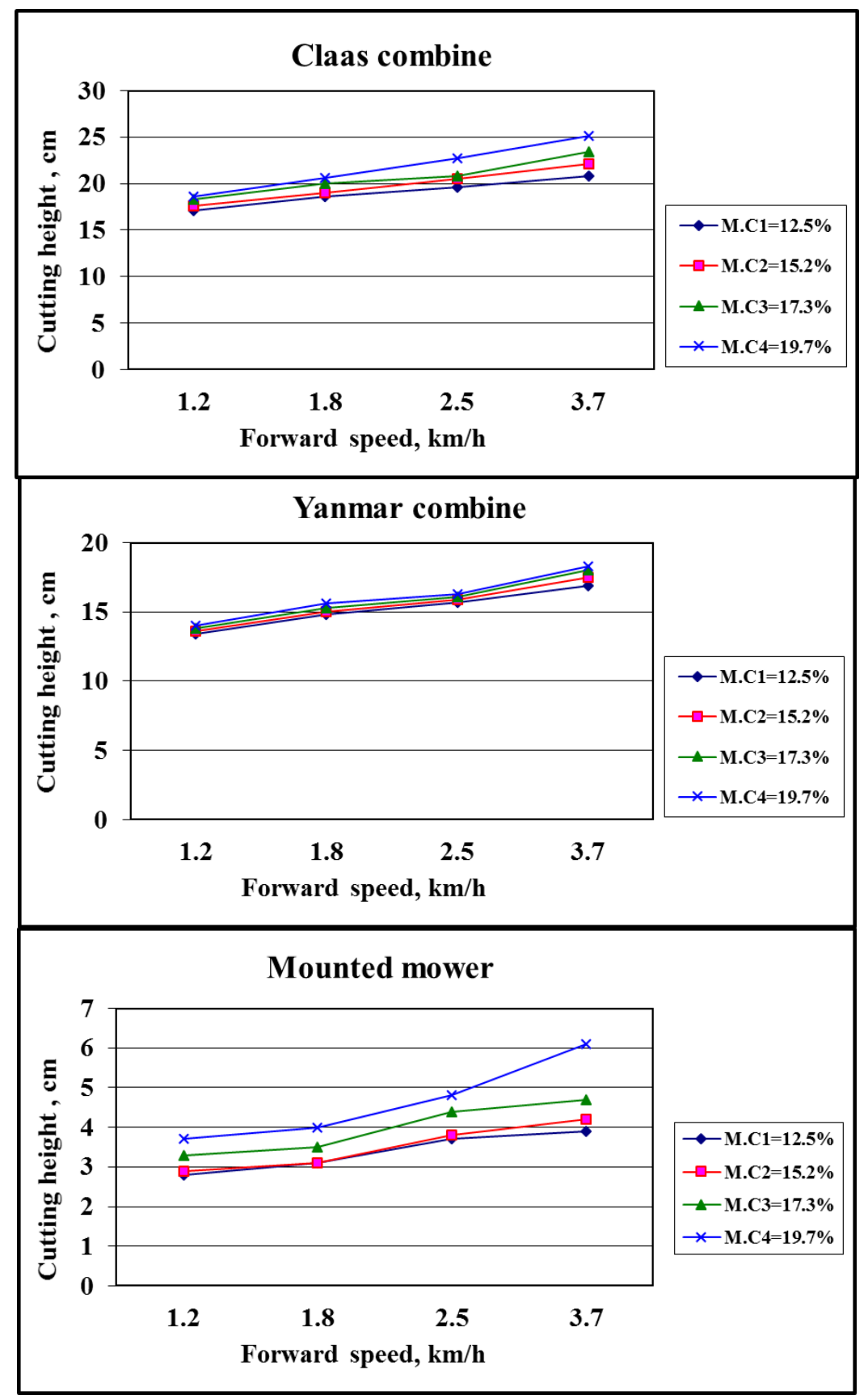

Fig. (6) Effect of forward speed on the cutting height of harvesting with using Claas, Yanmar combines and mounted mower under different moisture contents. 


\section{5- Actual field capacity and field efficiency:}

Fig. (7) show that with increasing forward speed from 1.2 to $3.7 \mathrm{~km} / \mathrm{h}$, actual field capacity increased from 0.91 to $1.71 \mathrm{fed} / \mathrm{h}$, from 0.33 to 0.77 $\mathrm{fed} / \mathrm{h}$ and 0.36 to $0.80 \mathrm{fed} / \mathrm{h}$ under Claas, Yanmar combines and front mounted mower respectively. While at increasing forward speed from 1.2 to $3.7 \mathrm{~km} / \mathrm{h}$, field efficiency decreased from $70.54 \%$ to $43.18 \%$, from $82.5 \%$ to $62.60 \%$ and 83.72 to $60.61 \%$ under Claas, Yanmar combines and front mounted mower respectively. This is may be due to the Claas combine has large working width, so it consumed more time to maneuvering during the turnings after every travel in the field compared to Yanmar combine and the mounted mower.

\section{6- Effect of forward speed on energy requirement}

The energy requirement depends upon the consumed power as well as fuel consumption and the actual field capacity. As illustrated in Fig. (8) the specific energy consumption decreases by increasing the forward speed from 1.2 to $3.7 \mathrm{~km} / \mathrm{h}$. This decrease can be attributed to the increase of the actual field capacity compared with the increase of the consumed power. The obtained results show that, the maximum values of consumed energy were 39.93, 39.27 and $29.83 \mathrm{~kW} . \mathrm{h} /$ fed for Claas, Yanmar combines and front mounted mower, respectively at forward speed of 1.2 $\mathrm{km} / \mathrm{h}$, while the minimum values of consumed energy were $25.68,21.34$ and $20.90 \mathrm{~kW} . \mathrm{h} /$ fed for Claas, Yanmar combines and front mounted mower respectively at forward speed of $3.7 \mathrm{~km} / \mathrm{h}$.

\section{7- Effect of forward speed on the criterion cost}

The criterion cost of the mechanical harvesting is mainly including operating cost and total grain losses cost. Fig. (9) show that the criterion cost increased with increasing forward speed from 1.2 to $3.70 \mathrm{~km} / \mathrm{h}$ for the three methods of harvesting at any value of moisture content of grain. The obtained results indicated that the grain moisture content of $19.7 \%$ and forward speed $1.8 \mathrm{~km} / \mathrm{h}$ gave the lowest criterion values were 374.48 ,499.24 and 796.7 LE/fed, the highest criterion cost value were 


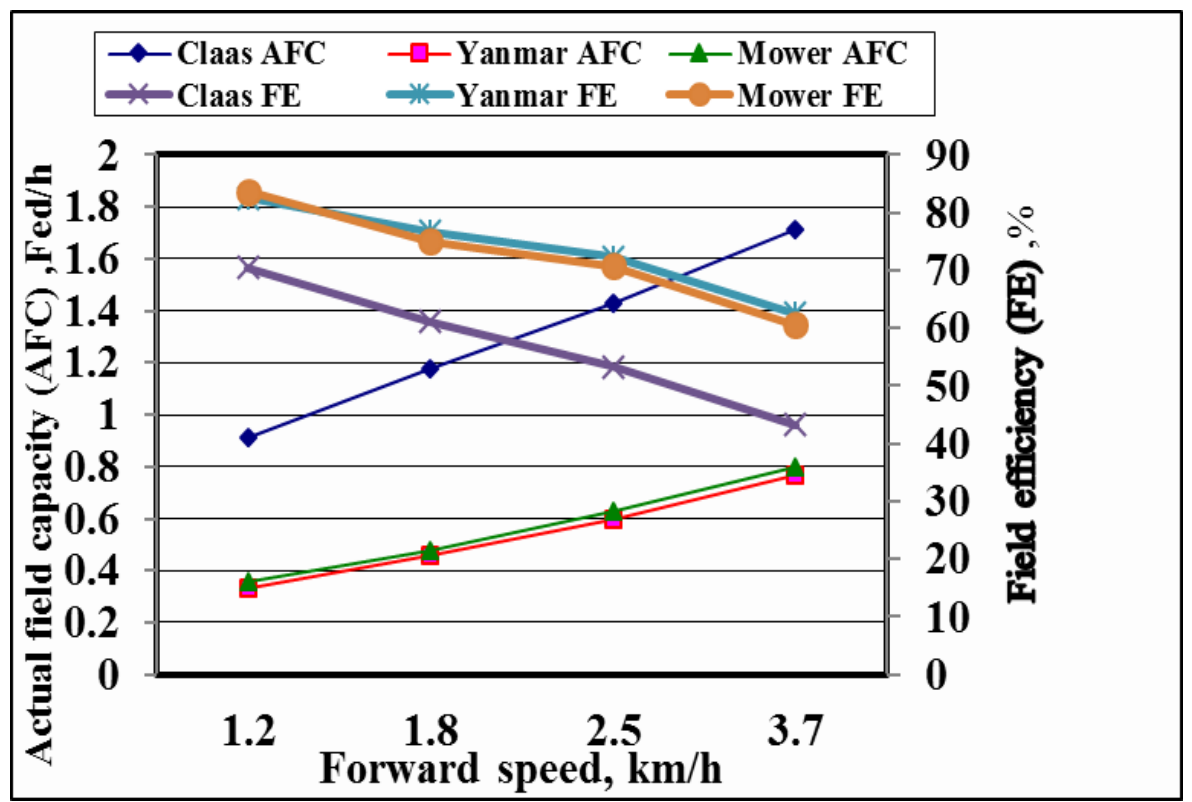

Fig. (7): The Actual field capacity and field efficiency for used harvesting machines.

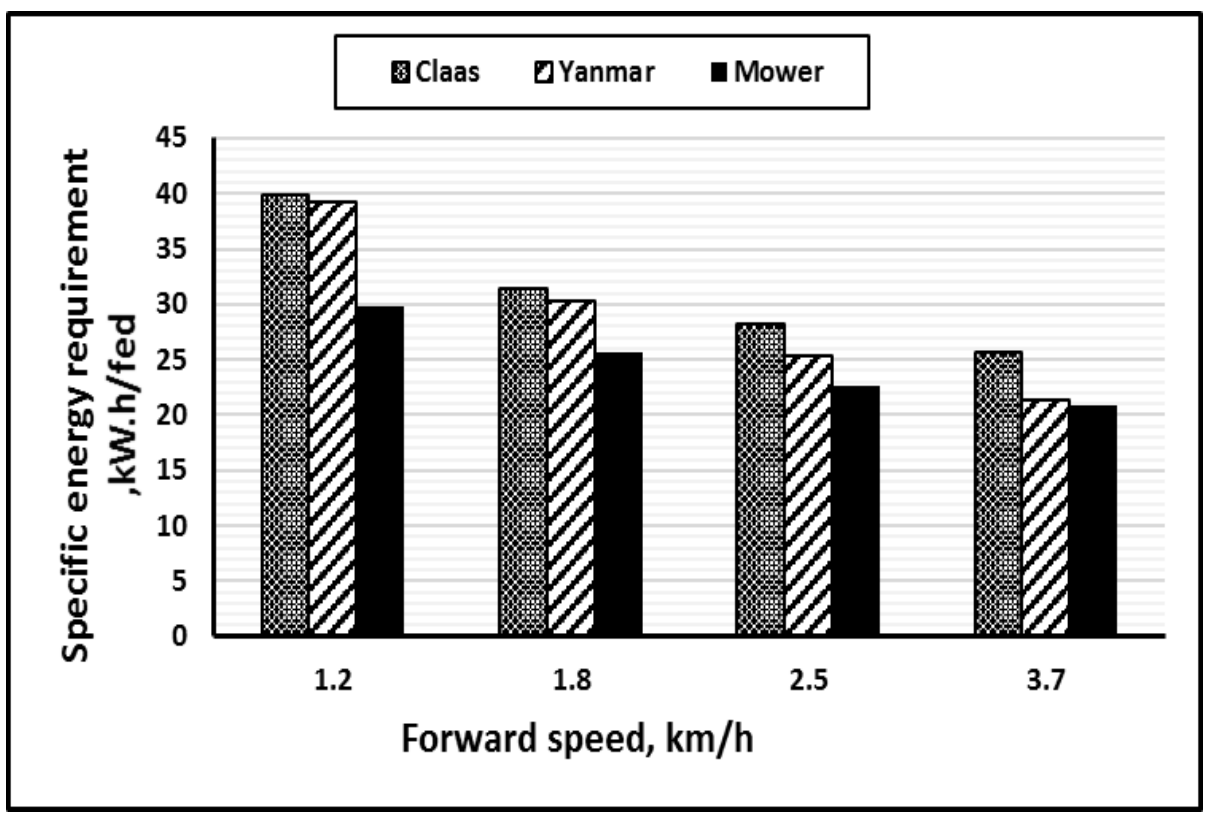

Fig. (8): The energy requirement for the used harvesting machines. 


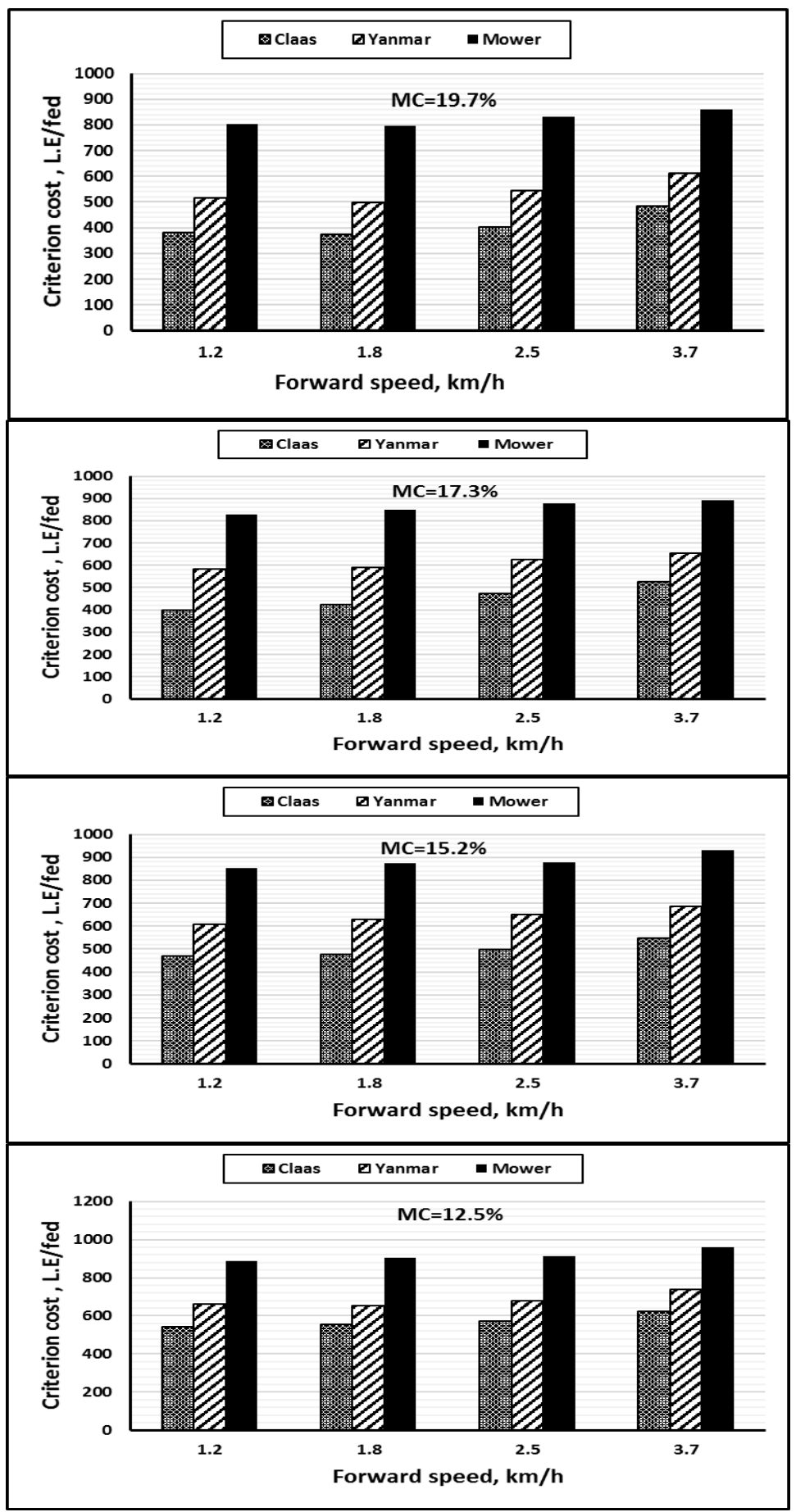

Fig. (9): The criterion cost for the used harvesting machines at different forward speeds and different moisture contents. 
$621.25,739.48$ and $959.69 \mathrm{LE} /$ fed at moisture content of $12.5 \%$ for Claas, Yanmar combines and front mounted mower then (by thresher machine) respectively. The lowest criterion cost of 374.48 L.E/fed was recorded at forward speed of $1.8 \mathrm{~km} / \mathrm{h}$ and at moisture content of $17.9 \%$ using the Claas combine. Also, the results indicated that the using of mower then by thresher gave a relatively high criterion cost because the threshing process needs to 4 labors at least with daily wage of 60 L.E for the manual collecting and feeding the thresher with wheat plants. It is clear that the using of Claas combine gave the lowest criterion cost compared to the Yanmar combine or the mounted mower. This may be due to the increase of field capacity resulting in the clear decrease in total grain losses costs. According to the obtained data, it is recommended to use the Claas, combine for harvesting the planted wheat crop on raised beds at forward speed of $1.8 \mathrm{~km} / \mathrm{h}$ and grain moisture content of $19.7 \%$ for achieving lowest criterion cost of 374.48 L.E/fed and actual field capacity of $1.18 \mathrm{fed} / \mathrm{h}$.

\section{CONCLUSION}

From the obtained results, this study recommended to use the Claas combine for harvesting the planted wheat crop on raised beds at forward speed of $1.8 \mathrm{~km} / \mathrm{h}$ and grain moisture content of $19.7 \%$ for achieving lowest criterion cost of $374.4 \wedge$ L.E/fed and actual field capacity of 1.18 $\mathrm{fed} / \mathrm{h}$.

\section{REFERENCES}

Awady, M.N. (1978). Tractor and farm machinery. Txt bk., Col. Agric. Ain Shams. U: 164-167.

Awady, M.N.; Ghoniem, E.Y. and Hashish, A.I. (1982). A critical comparison between wheat combines harvesters under Egyptian condition, Ain- Shams Univ.Cal. Ag. Res. Bul. No. 1920: 13 P.

Embaby, A.T. (1985). A comparison of the different mechanization systems for cereal crop production. M.Sc. Thesis Agric. Eng., Fac. Agric., Cairo Univ.

Hassen, M.A.; M.M. Morad; M.A. Eshazly and A. Farage (1994). Study on some operating parameters affecting the performance of 
combine devices with reference to grain losses. Misr J. of Agric. Eng., 11(3): 764- 780.

Ismail, Z.E.; M.M. Ibrahim and S.A. Embaby (2009). Economic evaluation and selection of farm machinery. Misr J. Agric. Eng., 26(4): 746-757.

Mostofi Sarkari MR (2011). Investigation and technical comparison of new and conventional wheat combines performance to improve and modification. Agricultural Engineering International: CIGR Journal 13 (3), 2011. Manuscript. No. 1510.

Moussa, A.L. (2008). Mechanical and Traditional harvesting methods for wheat crop. Misr J. Agric. Eng., 25(4): 1099-1111.

Siemens, M.C. and D.E. Hulick (2008). A new grain Harvesting collection, crop residue sizing, and grain segregation. American Society of Agricultural and Biological Engineers ISSN 0001-2351., 51(5): 1519-1527.

Spokas L.; Adamcuk V.; Bulgakov V. and Nozdrovicky L. (2016). The experimental research of combine harvesters. Res. Agric. Eng., 62: 106-112.

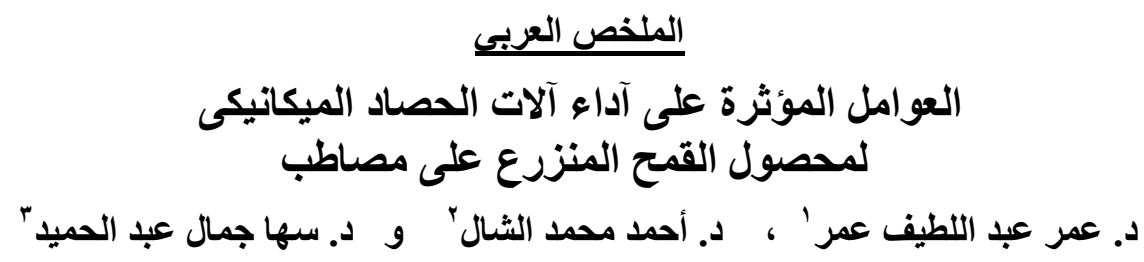

الهدف الرئيسي من هذه الدراسة هو إستخدام الحصاد الميكانيكى لمحصول القمح المنزر ع على لاعلى

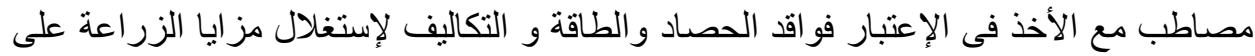

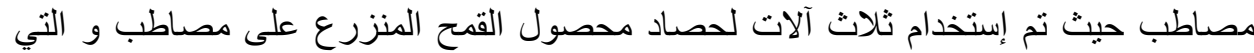

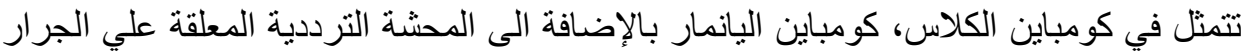

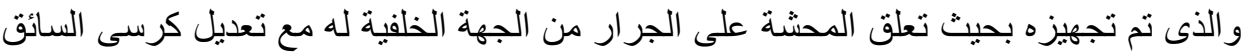
ليصبح العجل ذو المقاس الأكبر هو القائد لبعطى أعلى ثبات وأعلى كفاءة للمحشّة أثناء التشغيل

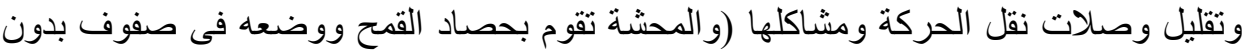
الحاجة للعمالة) و المتبو عة بآلة الدر اس الثابتة وتم اختبار هم و المقارنة بينهم. ' باحث أول بمعهد بحوث الهندسة الزراعية ـ الاقي - مصر.

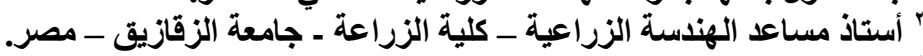

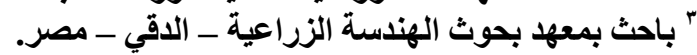




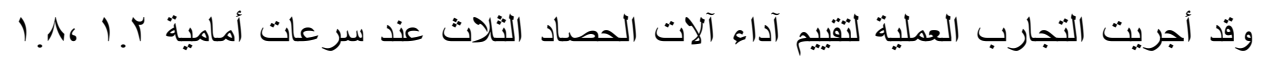

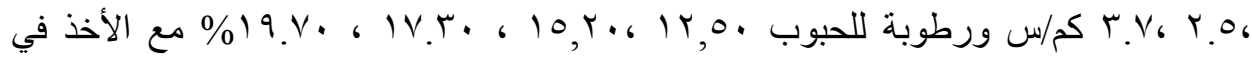

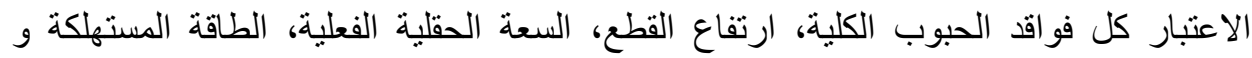

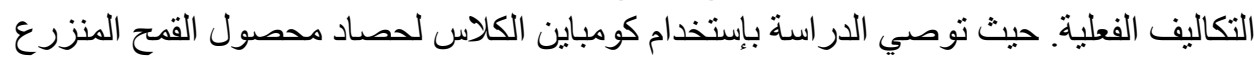

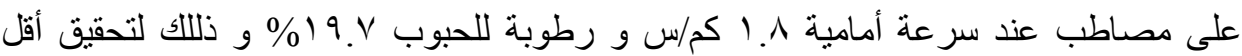

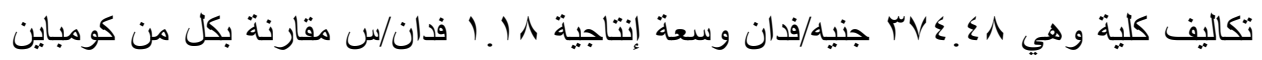

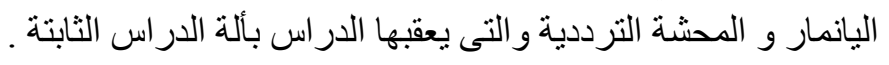

